\title{
Technology backstopping for management of insect pests and diseases of potato in farmer's field
}

\author{
Noorulla Haveri*, K.S. Nagaraja and K. Thulasiram \\ ICAR-Krishi Vigyan Kendra, Kolar (Karnataka) India
}

\section{ARITCLE INFO}

Received : 16.01 .2019

Revised : 05.03.2019

Accepted : 14.03 .2019

\section{KEY WORDS :}

Integrated insect pests, Diseases management, Frontline demonstration (FLD), Farmer's field school (FFS), Potato

*Corresponding author:

Email : noorulla4153@yahoo.com

\begin{abstract}
Integrated management practices in potato against major insect pests and diseases were demonstrated by ICAR-Krishi Vigyan Kendra, Kolar, Karnataka (India) through Frontline demonstration (FLD) and Farmer's field school (FFS) in the selected potato farmer's fields during 2015-16 and 2017-18. Effect of the demonstrated technologies on pest management was quite encouraging and resulted in reduction in mean mite incidence (1.46/leaf), defoliator incidence (0.49/plant) and potato tuber moth incidence (0.40/plant) as compared to farmer's practice plots. Similar effect was noted on disease management wherein demonstrated plots recorded least mean late blight incidence (4.96 PDI), early blight incidence (3.65 PDI) and Sclerotium wilt incidence $(0.82 \%)$ over the farmer's practice plots. These insect pests and diseases have major impact on crop yield. The average increase in potato tuber yield in demonstration plots was $3.63 \mathrm{t} / \mathrm{ha}$ $(19.13 \%)$ over farmers practice. Further, upon adoption of integrated management practices, growers have realized higher mean net returns (127982 Rs./ha) and benefit cost ratio (1.82) as against the farmers practice (82252 Rs./ha and 1.53 of net returns and benefit cost ratio, respectively). The difference in the yield was mainly due to adoption of integrated insect pests and disease management practices by the potato farmers as demonstrated by the KVK. Thus, the demonstrated technologies proved to be highly effective in management of insect pests and diseases compared to the existing farmers practice for the potato growers of the district.
\end{abstract}

How to view point the article : Haveri, Noorulla, Nagaraja, K.S. and Thulasiram, K. (2019). Technology backstopping for management of insect pests and diseases of potato in farmer's field. Internat. J. Plant Protec., 12(1) : 49-52, DOI : 10.15740/HAS/IJPP/12.1/49-52, Copyright @ 2019: Hind Agri-Horticultural Society. 